\title{
RENCANA ZONASI KAWASAN KONSERVASI MANGROVE DI DESA SUNGAI DUALAP KECAMATAN KUALA BETARA KABUPATEN TANJUNG JABUNG BARAT PROPINSI JAMBI
}

\author{
Mangrove Conservation Zonation Plan in Sungai Dualap Village Kuala Betara District Tanjung \\ Jabung Barat District Jambi Province
}

\author{
Djunaidi ${ }^{1}$, Rangga Bayu Kusuma Haris ${ }^{1}$, Perdana Putra Kelana ${ }^{1}$, \\ Tyas Dita Pramesthy ${ }^{1}$, dan Arumwati $^{2}$ \\ 1) Program Studi Penangkapan Ikan Politeknik Kelautan dan Perikanan Dumai \\ 2) Program Studi Penangkapan Ikan Politeknik Kelautan dan Perikanan Dumai \\ 3) Satuan Pengawasan Sumber Daya Kelautan dan Perikanan Palembang \\ Email : junbungo2016@gmail.com
}

\begin{abstract}
Abstrak
Keberadaan hutan mangrove di Desa Sungai Dualap memiliki potensi yang cukup besar mempunyai luas lebih kurang 450 ha dengan ketinggian tegakan 3-20 meter telah memberikan kontribusi kesuburan perairan laut Kecamatan Kuala Betara Kabupaten Tanjung Jabung Barat. Keadaan ini telah menjadikan Desa Sungai Dualap sebagai salah satu sentra produksi perikanan (ikan, udang, kepiting bakau, kerang dan lain sebagainya) di Kabupaten Tanjung Jabung Barat. Penelitian ini bertujuan untuk menelaah potensi dan kondisi mangrove serta menyusun rencana zonasi kawasan konservasi mangrove di Desa Sungai Dualap Kecamatan Kuala Betara Kabupatan Tanjung Jabung Barat Propinsi Jambi. Metode yang dilakukan dalam penelitian ini adalah melakukan kajian terhadap potensi dan kondisi mangrove yang ada di sepanjang wilayah pesisir Desa Sungai Dualap dan tersusunnya zonasi kawasan konservasi mangrove dalam mendukung konservasi dan rehabilitasi kawasan hutan mangrove di Desa Sungai Dualap. Hasil penelitian menunjukkan bahwa Rencana zonasi kawasan konservasi mangrove di Desa Sungai Dualap adalah seluas 601.49 ha yang terdiri dari zona inti dengan luas 432.35 ha, zona penyangga dengan luas 81.27 ha dan zona pemanfaatan/ekonomi seluas 87.87 ha. Jenis vegetasi mangrove yang ditemukan baik mangrove sejati maupun mangrove ikutan. Mangrove sejati meliputi jenis api-api (Avicennia marina), pidada (Sonneratia alba), bakau minyak (Rhizophora apiculata), bakau merah (Rhizophora stylos) nipah (Nypa fruticans), jeruju (Achantus ilicifolius), kalimuntung (Carbera mingas) dan lain sebagainya. Sedangkan mangrove ikutan yang dapat ditemui di sepanjang kawasan pesisir Desa Sungai Dualap seperti : nibung (Anchupermatrgillaria), paku laut (Agrostichum aereum), tuba laut (Derris trifoliate), pandan (Pandanus tectorius) dan seduduk (Melastomacandidum).
\end{abstract}

Kata Kunci: Ekosistem, Mangrove, Zonasi, Konservasi 


\section{PENDAHULUAN}

Kehidupan manusia sekarang ini sangat tergantung dengan keadaan alam di sekitar. Keadaan seperti ini sudah dapat terlihat pada beberapa masyarakat pedesaan yang menggantungkan pendapatannya dari sumberdaya alam yang ada (Arkham, 2018). Masyarakat di daerah pesisir sebagian besar sumber pendapatan dan sumber pangannya bergantung pada sumberdaya pesisir dan kelautannya. Kebanyakan masyarakat pesisir lebih memanfaatkan keberadaan dari ekosistem terumbu karang dan mangrove (Arkham et al, 2015). Ekosistem mangrove memiliki banyak peran secara fisik maupun biologis. Mangrove yang berfungsi sebagai penahan ombak, peredam angin dan perangkap sedimen merupakan contoh peran fisik, sedangkan untuk peran biologisnya adalah sebagai habitat bagi moluska, karena lingkungan mangrove menyediakan bahan organik (Kelana et al 2015). Ekosistem ini memiliki fungsi ekologis dan ekonomis yang sangat penting. Secara ekologis, ekosistem mangrove berfungsi sebagai daerah pemijahan (spawning grounds) dan daerah pembesaran (nursery grounds) berbagai biota perairan, selain itu serasah mangrove (berupa daun dan ranting) yang jatuh akan menjadi sumber pakan dalam lingkungan perairan setelah melalui proses dekomposisi (Tufliha et al, 2019)

Keberadaan hutan mangrove di Desa Sungai Dualap memiliki potensi yang cukup besar mempunyai luas lebih kurang 450 ha dengan ketinggian tegakan 3-20 meter telah memberikan kontribusi kesuburan perairan laut Kecamatan Kuala Betara Kabupaten Tanjung Jabung Barat. Keadaan ini telah menjadikan Desa Sungai Dualap sebagai salah satu sentra produksi perikanan (ikan, udang, kepiting bakau, kerang dan lain sebagainya) di Kabupaten Tanjung Jabung Barat. Dalam rangka usaha mempertahankan keberadaan ekosistem mangrove yang ada di Desa Sungai Dualap melalui Dinas Perikanan dan Kelautan Kabupaten Tanjung Jabung Barat telah melakukan beberapa kegiatan bekerjasama dengan Dinas Kelautan dan Perikanan Propinsi Jambi yang didukung oleh masyarakat setempat. Kegiatan tersebut meliputi : 1). Penetapan kawasan Daerah Perlindungan Laut (DPL) di Desa Sungai Dualap yang telah dirintis oleh masyarakat setempat pada tahun 2004, dan 2). Rehabilitasi mangrove Kabupaten Tanjung Jabung Barat dengan melakukan penanaman 10.000 batang mangrove pada tahun 2005.

Paradigma pembangunan kelautan dan perikanan semenjak bergulirnya era reformasi telah bergeser fungsi dan manfaat kelautan dan perikanan semula didominasi oleh aspek ekonomi bergeser menjadi aspek ekologi, sosial budaya dan ekonomi, sehingga dalam pemanfaatan khususnya sumberdaya ekosistem mangrove di lokasi penelitian ditemui beberapa permasalahan diantaranya adalah Permasalahan Ekologi, Permasalahan Sosial, Budaya dan Ekonomi, Permasalahan Kelembagaan, Permasalahan Hukum dan Peraturan, dan Sumberdaya Manusia. Tujuan dari penelitian ini adalah untuk Menelaah potensi dan kondisi mangrove di Desa Sumgai Dualap dan Menyusun rencana zonasi kawasan konservasi mangrove wilayah pesisir Desa Sungai Dualap.

\section{METODE PENELITIAN}

\section{Waktu dan Tempat Penelitian}

Penelitian ini dilaksanakan di Desa Sungai Dualap Kecamatan Kuala Betara Kabupaten Tanjung Jabung Barat. Waktu penelitian dilaksanakan selama 6 (enam) bulan, tahap persiapan dan survei dilakukan bulan Juni - Desember 2018.

\section{Metode Penelitian}

Metode yang digunakan dalam penelitian ini adalah Deskriptif, yaitu untuk memberikan gambaran dan penjelasan secara sistematis, faktual, dan akurat mengenai fakta-fakta dan gejala yang ada di lokasi penelitian dan Eksperimen, yaitu melakukan survei, pengambilan data, pengamatan langsung di lapangan. Penentuan stasiun penelitian dan pengambilan sampel dilakukan dengan metode purposive sampling berdasarkan fungsi dan manfaat lingkungan. Untuk menentukan stasiun penelitian dan pengambilan sampel diukur dengan menggunakan GPS (Global Position System).

\section{Analisis Data}

Dalam menganalisis data terhadap potensi dan kondisi mangrove dan penyusunan zona ruang kawasan mangrove wilayah pesisir Desa Sungai Dualap, selain dilakukan dengan analisis kuantitatif dan dilakukan analisis kualitatif meliputi Analisis Potensi dan Kondisi Mangrove dan Analisis Kesesuaian Zona Ruang Kawasan Konservasi Mangrove.

\section{HASIL DAN PEMBAHASAN}

\section{Potensi dan Kondisi Kelautan dan Perikanan Desa Sungai Dualap \\ a. Perikanan \\ Bagian Barat dari Desa Sungai Dualap} langsung berhadapan dengan perairan Selat Berhala yang memiliki potensi perikanan laut yang cukup besar. Tingkat pengusahaan perikanan cukup tinggi dengan berbagai bentuk alat tangkap yang digunakan baik yang bersifat aktif maupun pasif. 
Nelayan di Desa Sungai Dualap umumnya adalah nelayan skala kecil yang biasanya beroperasi di daerah perairan pantai atau kalaupun lebih ke tengah tidak jauh dari jarak 4 mil dari pantai. Nelayan tersebut umumnya memiliki lebih dari satu macam alat tangkap terutama mereka yang mengoperasikan alat tangkap jaring, sedangkan nelayan yang mempunyai alat tangkap menetap (perangkap) biasanya mempunyai satu macam alat tangkap saja. Perahu yang digunakan pada umumnya di bawah 5 GT dengan kekuatan mesin berkisar antara 5-40 PK. Karakteristik nelayan skala kecil dan adalah untuk memahami karakteristik dari nelayan skala kecil, mulai dari alat tangkap yang digunakan, ketergantungannya terhadap keberadaan ekosistem dan habitat, jenis tangkapan dominan, fishing ground, dan karakteristik lainnya yang berkaitan dengan sumberdayanya (Arkham et al, 2018)

Jenis ikan yang umumnya tertangkap adalah jenis ikan pelagis, ikan demersal dan jenis udang. Jenis ikan pelagis yang tertangkap yang tercatat dalam statistik perikanan Kecamatan Kuala Betara yang utamanya adalah Ikan Layang, Ikan Tetengkek, Ikan Belanak, Ikan Kembung dan Ikan Tenggiri. Jenis Ikan Demersal yang utama adalah Ikan Senangin, Ikan Gulamah, Ikan Parang-parang, Ikan Pari dan Ikan Mayung dan dari jenis Udang berupa Udang Krosok, Udang Dogol, Udang Putih dan Udang Windu DKP Tanjung Jabung Barat (2015). Hasil penelitian yang telah dilakukan di lokasi penelitian, jenis ikan yang berhasil ditemui sebanyak 22 jenis dari 17 famili, jenis udang yang berhasil ditemui sebanyak 6 jenis dari 2 famili dan jenis Famili Gastropoda terdapat 6 jenis, Famili Bivalvia 1 jenis dan Famili Brachyura 3 jenis.

\section{b. Ekosistem Mangrove di Lokasi Penelitian}

Potensi hutan mangrove yang ada di Desa Sungai Dualap menurut data yang ada sekitar 281,1ha, (Dinas Perikanan dan Kelautan Kab. Tanjung Jabung Barat, 2015), sementara hasil dari pengolahan data GIS luas mangrove di Desa Sungai Dualap adalah 356.88 ha. Vegetasi hutan mangrove yang terdapat di kawasan ini memiliki keanekaragaman jenis yang tinggi yang didominasi oleh jenis famili Rhizophoraceae, (Rhizophora, Bruguiera dan Ceriops), Sonneratiaceae, (Sonneratia), Avicenniaceae (Avicennia) dan Meliaceae (Xylocarpus). Selain itu juga terdapat famili Pteridaceae (Acrostichum aureum), Myrsinaceae (Aegiceras), Palmae (Nypa frusticans), Acenthaceae (Acanthus ilifolius) dan Malvaceae (Hibiscus filiaceus) dengan tinggi rata-rata 3-20 meter.

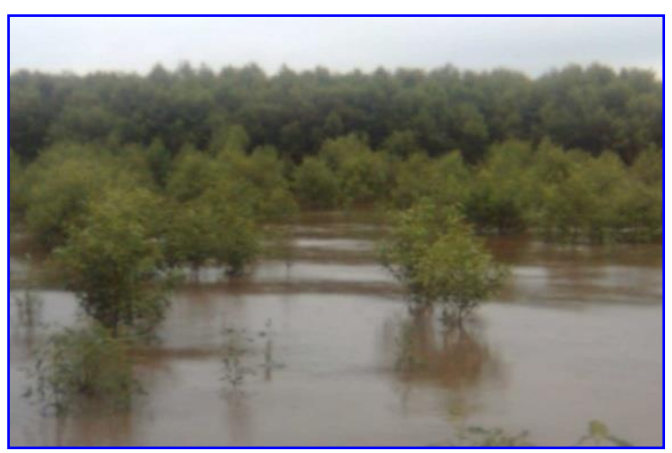

Gambar 1. Mangrove Di Lokasi Penelitin Bila potensi mangrove di Desa Sungai Dualap dibagi ke dalam 4 (empat) zona maka zona yang paling dekat dengan laut, dengan substrat agak lumpur ditumbuhi oleh jenis Avicennia, pada zona ini biasanya berasosiasi Sonneratia yang dominan tumbuh pada lumpur dalam dan kaya akan bahan organik. Zona berikutnya lebih ke arah darat, hutan mangrove umumnya didominasi oleh Rhizophora, di zona ini juga dijumpai Bruguiera dan Xylocarpur. Zona berikutnya di dominasi oleh jenis Bruguiera dan zona transisi antara hutan mangrove dengan hutan daratan rendah biasanya ditumbuhi oleh jenis Nypa Fruticans dan beberapa spesies palem lainnya. Magrove dapat dibedakan ke dalam beberapa zonasi berdasarkan jenis pohon penyusun yang dominan (Bengen, 2000). Kawasan mangrove merupakan kawasan yang berfungsi jembatan antara lautan dengan daratan yang mempunyai fungsi ekologis sebagai pelindung pantai, mencegah abrasi, habitat aneka biota perairan, tempat mencari makan, tempat asuhan dan pembesaran ikan atau udang (Pramesthy dan Maro, 2019)

\section{c. Perairan Estuaria}

Wilayah pesisir Desa Sungai Dualap kaya akan potensi sumberdaya alam estuaria. Kebanyakan estuaria didominasi oleh substrat berlumpur yang kaya bahan organik dan menjadi cadangan makanan utama bagi organisme estuaria. Karena merupakan kawasan pertemuan antara air laut dan air tawar, maka organisme dan tumbuhan yang berkembang di estuaria relatif sedikit.

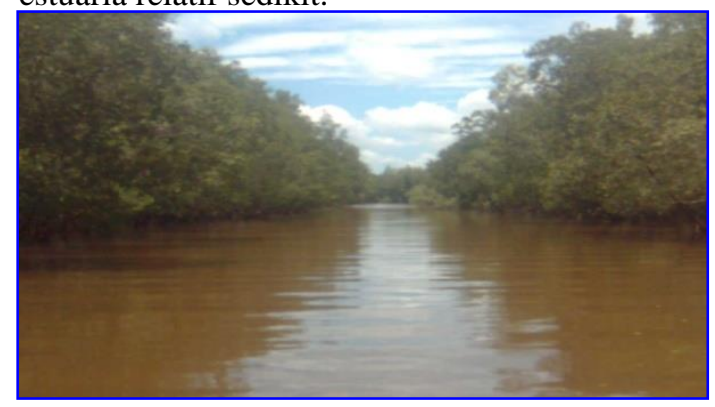

Gambar 2. Estuaria Di Lokasi Penelitian 
Tipe estuaria yang terdapat di lokasi penelitian adalah estuaria berstratifikasi sebagian/parsial, luas diperkirakan sekitar 15 ha dengan kedalaman berkisar antara 13 - 15 meter (Dinas Perikanan dan Kelautan Kab. Tanjung Jabung Barat, 2016), sementara hasil dari pengolahan data GIS luas perairan estuaria di Desa Sungai Dualap adalah 23.50 ha. Pada estuaria ini, aliran air tawar dari sungai seimbang dengan air laut yang masuk melalui arus pasang. Percampuran air dapat terjadi karena adanya turbulensi yang berlangsung secara berkala oleh aksi pasang surut.

Peraiaran estuaria Desa Sungai Dualap yang relatif luas tersebut telah mendukung perkembangan tumbuhnya organisme flora dan fauna di sekitar estuaria seperti mangrove, ikan, udang, kepiting bakau, rajungan dan kerang-kerangan (moluska) sehingga telah memberikan manfaat yang tidak ternilai bagi masyarakat Desa Sungai Dualap. Kehidupan masyarakat sehari-hari sangat tergantung dengan keberadaan perairan estuaria ini. Selain itu perairan estuaria di kawasan ini juga merupakan produsen dan gudang penyimpanan zat hara yang setiap waktu dapat didistribusikan ke laut melalui kanal-kanal dan muara-muara sungai yang ada saat air surut terjadi sebagai pupuk kehidupan lautan, sehingga organisme lautpun tumbuh dan berkembang demi kesejahteraan manusia yang ada di sekitarnya maupun yang jauh dari tempat ini.

\section{d. Perairan Pantai}

Pantai adalah sabuk penghubung antara lautan dan daratan yang terletak antara garis surut terendah dan pasang air tertinggi pada suatu tempat. Pantai terdiri dari jenis pantai berbatu, pantai berpasir dan pantai berlumpur. Pantai berlumpur merupakan kombinasi ukuran partikel yang berbeda dan variasi faktor lingkungan menciptakan suatu kisaran habitat pantai berlumpur. Jenis pantai ini mendominasi pantai yang ada di Desa Sungai Dualap dengan panjang garis pantai sekitar $1 \mathrm{~km}$ dengan struktur berlumpur.

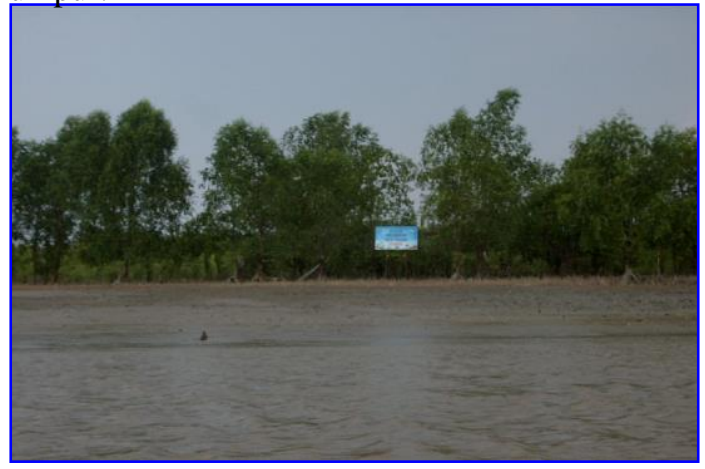

Gambar 3. Bentuk Peraiaran Pantai Desa Sungai Dualap
Arnold dan Birtles (1989) menyatakan bahwa Pantai berlumpur adalah tipe pantai yang khas yang memiliki ciri-ciri fisik yang berbeda dibandingkan dengan ciri-ciri fisik pantai berpasir dan pantai berbatu. Beberapa ciri fisik pantai berlumpur adalah : 1). Substrat yang menyusun sedimen dalah lumpur yang kaya zat organik, 2). Tofografinya sangat landai sehingga air dapat tertahan lebih lama di dalam substrat, 3). Posisinya secara geografis biasanya menepati daerah teluk dan 4). Kekuatan ombak yang bekerja di panatai relatif lemah.

\section{Analisis Kesesuaian Zona Ruang Kawasan Mangrove Desa Sungai Dualap}

Berdasarkan hasil pengolahan data kesesuaian zona ruang untuk kawasan konservasi mangrove di Desa Sungai Dualap dapat dianalisis bahwa tidak semua lokasi penelitian layak untuk dijadikan kawasan konservasi mangrove khususnya zona inti. Dari 9 (sembilan) stasiun penelitian yang diteliti, ternyata ada 6 (enam) stasiun yang cocok untuk dijadikan zona inti yaitu stasiun 3 dengan nilai kelayakan 65,87, stasiun 4 dengan nilai kelayakan 66,62, stasiun 5 dengan nilai kelayakan 64,12, stasiun 6 dengan nilai kelayakan 64,12, stasuin 7 dengan nilai kelayakan 64,12 dan stasiun 8 dengan nilai kelayakan 62,75. Sementara ada 3 (tiga) stasiun yang kurang layak dan dijadikan zona penyangga dan zona pemanfaatan/ekonomi yaitu stasiun 1 dengan nilai 35,25 dan stasiun 2 dengan nilai 35,68 untuk zona pemanfaatan/ekonomi dan stasiun 9 dengan nilai 34,81 untuk zona penyangga. Hasil analisis kesesuaian zona ruang kawasan konservasi mangrove di wilayah pesisir Desa Sungai Dualap dapat dijelaskan sebagai berikut :

\section{a. Zona Inti}

Zona inti di lokasi penelitian memiliki nilai konservasi yang tinggi sangat rentan terhadap gangguan atau perubahan dan hanya dapat mentolerir sedikit aktivitas manusia. Zona ini harus dikelola dengan tingkat perlindungan yang tinggi serta tidak dapat diizinkan adanya aktivitas eksploitasi. Dalam pengelolaan zona ini harus mendapat perlindungan yang maksimum, kegiatan yang dapat dilakukan pada zona ini antara lain penelitian dan pengembangan yang menunjang pemanfaatan, ilmu pengetahuan, pendidikan, kegiatan penunjang budidaya dan wisata alam terbatas.

Berdasarkan hasil pengolahan data kesesuaian zonasi ruang di atas, lokasi yang termasuk kedalam zona inti adalah stasiun 3, 4, 5, 6 dan stasiun 7. Dari hasil pengolahan data GIS, luas zona inti yang di dapat adalah seluas 432.35 ha yang terdiri dari luas mangrove 356.88 ha dan luas zona inti 75.47 ha. 


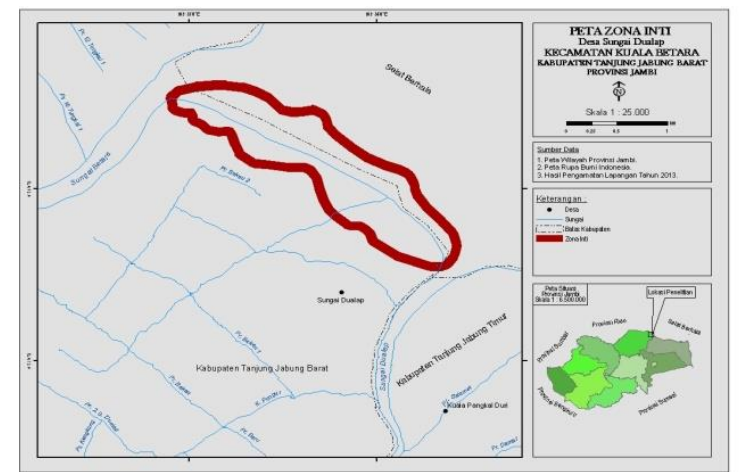

Gambar 4. Peta Zona Inti Kawasan Konservasi Mangrove Desa Sungai Dualap.

Menurut Supriharyono (2007), zona inti merupakan zona yang dilindungi. Pada zona ini tidak diperkenankan adanya kegiatan umum, terkecuali kegiatan yang berhubungan dengan ilmu pengetahuan, pendidikan dan penelitian yang mempunyai izin dari pengelola kawasan.

\section{b. Zona Penyangga}

Zona penyangga di lokasi penelitian bersifat lebih terbuka, tetapi tetap dikontrol dan beberapa bentuk pemanfaatan masih dapat diizinkan. Penyangga di sekeliling zona konservasi ditujukan untuk menjaga kawasan konservasi dari berbagai aktivitas pemanfaatan yang dapat mengganggu dan melindungi kawasan konservasi dari pengaruh luar. Berdasarkan hasil pengolahan data kesesuaian zonasi ruang di atas, lokasi yang termasuk kedalam zona penyangga adalah stasiun 9. Dari hasil pengolahan data GIS, luas zona penyangga yang didapat adalah seluas 81.27 ha.

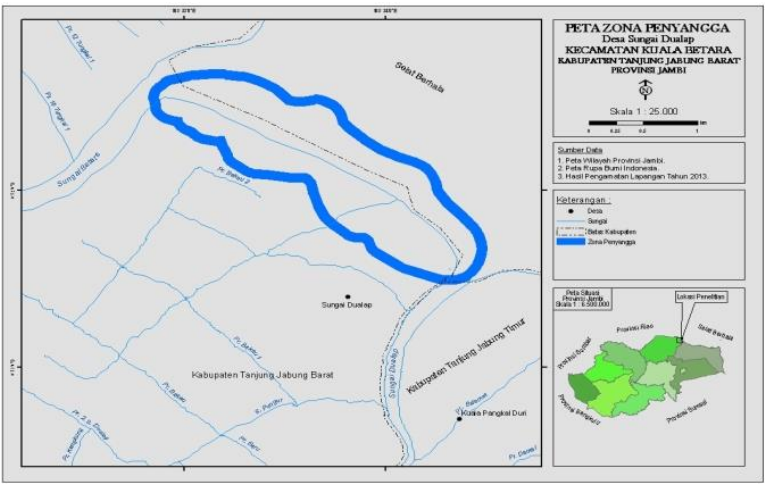

Gambar 5. Peta Zona Penyangga Kawasan Konservasi Mangrove Desa Sungai Dualap.

Supriharyono (2007), menyatakan bahwa zona penyangga merupakan daerah penahan (penyangga) gangguan dari luar terhadap kawasan konservasi dengan harapan ekosistem dalam kawasan konservasi tetap terjaga. Sesuai dengan peruntukannya, pada zona ini kegiatan yang ada lebih diarahkan pada pemanfaatan sumberdaya alam secara terkendali, seperti penangkapan ikan secara tradisional dan pemanfaatan lain yang menunjang kehidupan masyarakat setempat.

Zona penyangga merupakan kawasan penting sebagai pendukung kawasan inti konservasi dan merupakan zona yang sangat potensial untuk dikelola guna mempertahankan kelestarian biodiversitas dan ekosistem pesisir dan laut, baik sebagai penyangga kawasan konservasi, kawasan budidaya, kawasan wisata bahari dan sumber penghasilan bagi nelayan

Direktorat Tata Ruang Laut Pesisir dan PulauPulau Kecil, Departemen Kelautan dan Perikanan (2010) menyatakan bahwa zona penyangga merupakan zona perlindungan yang di dalamnya terdapat satu atau lebih zona inti. Zona ini biasanya tardiri dari satu atau lebih vegetasi alamiah yang harus disisakan di sepanjang perairan wilayah pesisir dan pulau-pilau kecil. Zona ini berfungsi untuk menjebak sedimentasi dan melindungi kualitas air. Zona penyangga dapat dimanfaatkan secara sangat terbatas yang didasarkan atas pengaturan yang ketat.

\section{c. Zona Pemanfaatan/Ekonomi}

Berdasarkan hasil pengolahan data kesesuaian zonasi ruang di atas, lokasi yang termasuk kedalam zona pemanfaatan/ekonomi adalah stasiun 1 dan 2 . Dari hasil pengolahan data GIS, luas zona pemanfaatan/ekonomi yang didapat adalah seluas 87.87 ha.

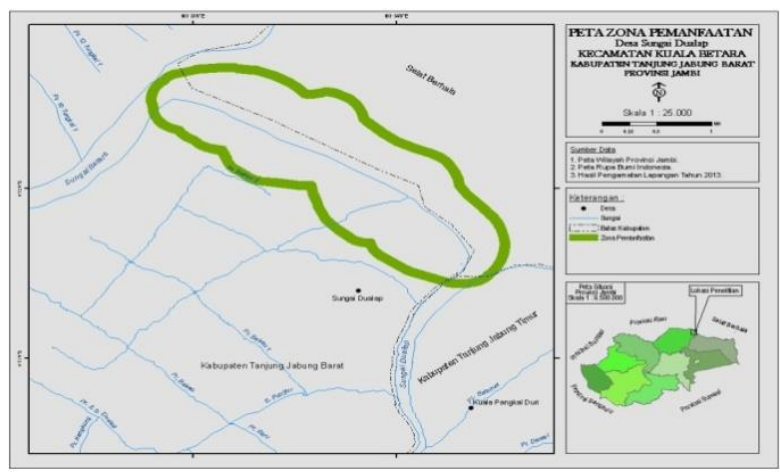

Gambar 6. Peta Zona Pemanfaatan / Ekonomi Kawasan.

Suprihariyono (2007) menyatakan bahwa zona pemanfaatan/ekonomi merupakan daerah pemanfaatan sumberdaya alam oleh penduduk setempat secara tradisional untuk kepentingan hidup sehari-hari dan peningkatan pendapatan maupun oleh pengunjung/pendatang dengan pengawasan, tetapi dengan pembatasan-pembatasan tertentu yang berkaitan dengan kemungkinan gangguan terhadap habitat dan pengambilan jenis yang langka dan atau terancam punah. Magrove yang seharusnya merupakan pelindung dari gangguan aktivitas dari laut sudah mulai berkurang karena adanya aktivitas manusia dan kondisi alamiah lainnya yang 
mempengaruhi Dalam upaya mengidentifikasi masalah kegagalan perlu pemilihan persoalan antara teknis operasional, manajemen internal dan kondisi mutlak diperlukan (Haris et al, 2017).

Direktorat Tata Ruang Laut Pesisir dan PulauPulau Kecil, Departemen Kelautan dan Perikanan (2010) menyatakan bahwa zona pemanfaatan/ekonomi masih memiliki nilai konservasi tertentu, tetapi dapat mentolerir berbagai tipe pemanfaatan oleh manusia, dan layak bagi beragam kegiatan eksploitasi yang diizinkan dalam suatu kawasan konservasi. Zona ini didapatkan melalui proses pemilihan secara akademis dan kemauan politik.

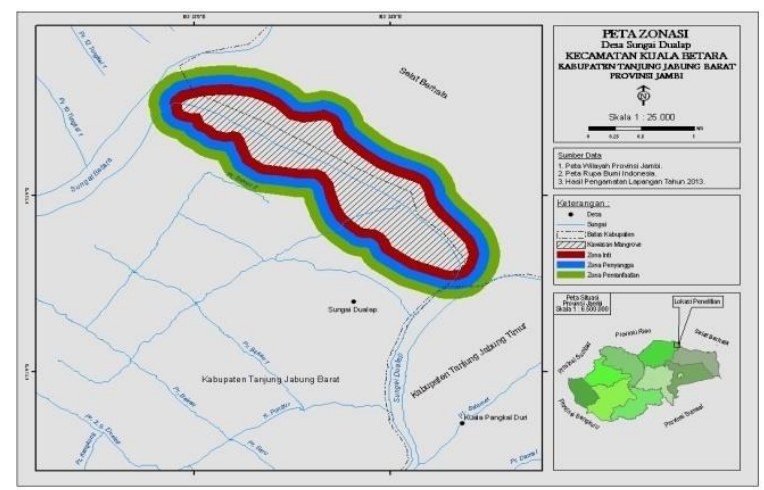

Gambar 7. Peta Zonasi Kawasan Konservasi Mangrove

\section{KESIMPULAN DAN SARAN}

\section{Kesimpulan}

Berdasarkan hasil penelitian dan analisis yang telah dilakukan, maka dapat disimpulkan bahwa :

a. Rencana zonasi kawasan konservasi mangrove di Desa Sungai Dualap adalah seluas 601.49 ha yang terdiri dari zona inti dengan luas 432.35 ha, zona penyangga dengan luas 81.27 ha dan zona pemanfaatan/ekonomi seluas 87.87 ha.

b. Jenis vegetasi mangrove yang ditemukan baik mangrove sejati maupun mangrove ikutan. Mangrove sejati meliputi jenis api-api (Avicennia marina), pidada (Sonneratia alba), bakau minyak (Rhizophora apiculata), bakau merah (Rhizophora stylos) nipah (Nypa fruticans), jeruju (Achantus ilicifolius), kalimuntung (Carbera mingas) dan lain sebagainya. Sedangkan mangrove ikutan yang dapat ditemui di sepanjang kawasan pesisir Desa Sungai Dualap seperti : nibung (Anchupermatrgillaria), paku laut (Agrostichum aereum), tuba laut (Derris trifoliate), pandan (Pandanus tectorius) dan seduduk (Melastomacandidum).

\section{Saran}

1. Diperlukan peningkatan sosialisasi menyeluruh dan berkelanjutan kepada masyarakat mengenai program-program pemerintah khususnya tentang rencana kawasan konservasi wilayah pesisir dan laut khususnya zonasi kawasan konservasi mangrove di Desa Sungai Dualap.

2. Dalam pelaksanaan program, hendaknya masyarakat diikutsertakan secara aktif mulai dari proses perencanaan sampai terwujudnya kawasan konservasi wilayah pesisir dan laut khususnya zonasi kawasan konservasi mangrove di Desa Sungai Dualap.

3. Diperlukan adanya kesinambungan program kawasan konservasi wilayah pesisir dan laut yang melibatkan secara aktif seluruh stakeholder (pemerintah pusat dan daerah serta masyarakat). Selain itu perlu dibuat PERDA untuk menjamin keberadaan kawasan konservasi wilayah pesisir dan laut khususnya konservasi mangrove di Desa Sungai Dualap.

\section{DAFTAR PUSTAKA}

Arkham, M.N, Adrianto, L dan Wardiatno, Y. 2015. Studi Keterkaitan Ekosistem Lamun dan Perikanan Skala Kecil (Studi Kasus: Desa Malang Rapat dan Berakit, Kabupaten Bintan, Kepulauan Riau). Jurnal Sosek KP. 10 (2) : $137-148$

Arkham, M.N. 2018. Jasa Penyediaan Ekosistem Lamun Terhadap Aktivitas Perikanan Skala Kecil di Daerah Pesisir Timur Pulau Bintan, Kepulauan Riau. Costal and Ocean Journal. 1(3) : 29-40.

Arkham, M.N, Trihandoyo, A dan Ramli, A. 2018. Keterkaitan Perikanan Skala Kecil dan Sumberdaya Krustasea di Perairan Utara Madura: Studi Konektivitas Sosial-Ekologi. Costal and Ocean Journal. 1(3) : 1-10.

Bengen. 2000. Pedoman Teknis Pengenalan dan Pengelolaan Ekosistem Magrove. Pusat Kajian Sumberdaya Pesisr dan Lautan. Institut Pertanian Bogor. Bogor.

Departemen Kelautan dan Perikanan, 2003. Pedoman Penetapan Kawasan Konservasi Laut Daerah, Direktorat Konservasi dan Taman Nasional Laut, Direktorat Jenderal Pesisir dan PulauPulau Kecil. Jakarta.

Departemen Kelautan dan Perikanan 2002. Keputusan Menteri Kelautan dan Perikanan No. 34 Tahun 2002 Tentang Pedoman Umum Penataan Ruang Pesisir dan Pulau-pulau Kecil. Departemen Kelautan dan Perikanan. Jakarta.

Direktorat Tata Ruang Laut Pesisir dan Pulau-Pulau Kecil, 2010. Pedoman Teknis Tata Ruang 
Wilayah Pesisir dan Pulau-Pulau Kecil, Jakarta.

Dinas Kelautan dan Perikanan Kabupaten Tanjung Jabung Barat, 2015. Survei dan Pemetaan Detil Lokasi terpilih (Kawasan Konservasi dan Mariculture) Kabupaten Tanjung Jabung Barat.

Dinas Kelautan Dan Perikanan Kabupaten Tanjung Jabung Barat, 2015. Studi Pengembangan Potensi Sumberdaya Perikanan dan Kelautan Wilayah Kabupaten Tanjung Jabung Barat Propinsi Jambi, Draft Laporan Akhir.

Esri, 2000, GIS for School and Libraries Version 5, Environmental System Research Institute.

Haris, R.B.K, Nurbambang, A dan Anggoro, S. 2017. Analisis Prospek Pengembangan Usaha Pembesaran Ikan Bandeng (Chanos chanos Forskal 1775) di Kecamatan Tugu Kota Semarang Provinsi Jawa Tengah. Jurnal Ilmiah AgrIBA. 5(1): 70-83

Kelana, P.P, Setyobudi, I dan Krisanti, M. 2015. Kondisi Habitat Polymesoda erosa pada
Kawasan Ekositem Magrove Cagar Alam Leuweung Sacang. Jurnal Akuatika Indonesia. $6(2): 107-117$.

Pramesthy, T.D dan Maro, J.F. 2019. Persepsi Masyarakat Kelurahan Welai Timur dan Kelurahan Welai Barat tentang Rehabilitas dan Pengelolaan Hutan Magrove. Jurnal Agroqua. 17 (1) : $58-66$.

Supriharyono. 2007. Konservasi Ekosistem Sumberdaya Hayati Di Wilayah Pesisir dan Laut Tropis. Pustaka Pelajar Yogyakarat.

Supriharyono. 2000. Pelestarian dan Pengelolaan Sumberdaya Alam di Wilayah Pesisir Tropis. Penerbit PT. Gramedia Pustaka Utama, Jakarta.

Tufliha, A.R, Putra, D.M, Amara, D.M, Santika, R.M, Oktavian, SM dan Kelana, P.P. 2019. Kondisi Ekosistem Mangrove di Kawasan Ekowisata Karangsong Kabupaten Indramayu. Jurnal Akuatika Indonesia. 4(1) : 11-16 